\title{
Flora Endemic Rare and Bioclimate of Palestine
}

\author{
Jehad M. H. Ighbareyeh1,2*, A. Cano-Ortiz¹, E. Cano Carmona1, Asma A. A. Suliemieh2, \\ Mohammed M. H. Ighbareyeh²
}

${ }^{1}$ Faculty of Experimental Sciences, Department of Animal and Plant Biology and Ecology, University of Jaen, Jaen, Spain

${ }^{2}$ Faculty of Agriculture, Al-Quds Open University, Hebron, Palestine

Email: *jehadighbareyeh@hotmail.com

How to cite this paper: Ighbareyeh, J.M.H., Cano-Ortiz, A., Carmona, E.C., Suliemieh, A.A.A. and Ighbareyeh, M.M.H. (2017) Flora Endemic Rare and Bioclimate of Palestine. Open Access Library Journal, 4: e3977. https://doi.org/10.4236/oalib.1103977

Received: September 26, 2017

Accepted: October 30, 2017

Published: November 2, 2017

Copyright $\odot 2017$ by authors and Open Access Library Inc.

This work is licensed under the Creative Commons Attribution International License (CC BY 4.0).

http://creativecommons.org/licenses/by/4.0/

\begin{abstract}
Palestine was subject to classification study through the period from February to May 2017. This area has a characteristic of flora and biodiversity and belongs to dry, arid, semi-arid, sub-humid and humid climates, and locates in Mediterranean region. We took 400 samples of different plant species from Hebron (Idna, Althahreiyeh, Yatta villages and Hebron city); Jenin (Jenin city, Al-Yamon, Maysalon and Yabod); Jericho (Wadi Al-Qalt, Ain or Tal Sultan and Al-Nwehmeh) and Ramallah (Safa, Turmus Aya and Qibia). The absence of classification studies on the areas led us to run a statistical treatment on the 400 sampled flora of Palestine. Moreover, the classification was made following Braun-Blanquet in 1979; we transformed the Braun-Blanquet species abundance-dominance values into those of Van der Maarel in 1979. In the statistical treatment we obtained more than 53 plant species (Endemic rare) as Paronychia palaestina Eig, Trifolium palaestinum Boiss., Trifolium philistaeum Zohary, Suaeda philistaeum Zoharyand, and others, representing forests, copses, herbaceous and high shrublands influenced by climate (climatophilous), and edaphohygrophilic, and bioclimate factors as ombrotype and thermotype. However, according to study area we indicated that the flora endemic rare has 53 species, which of them $13 \%$ belong to Compositae family, 7.54\% Poaceae, Liliaceae \& Papilionaceae families, and $5.66 \%$ Iridaceae family.
\end{abstract}

\section{Subject Areas}

Plant Science

\section{Keywords}

Palestine, Classification, Biology, Endemic, Flora 


\section{Introduction}

Palestine has a wide range of biodiversity concerns with a large variety of plants, and particular geographic location, between Asia, Africa and European and in conjunction with a series of environmental, bioclimatology and climatology factors, making it a very fertile land and unique biodiversity [1] [2]. Climate and bioclimate factors played an important role in influence on plant communities [3], flora and biological resources and plant physiology, biology and production [1]-[18]. The flora of Palestine includes 149 - 155 endemic species (6\% of the total flora), of which $43 \%$ are found to be common, $27.5 \%$ are rare and $25.6 \%$ are very rare [19]. Moreover, it is the meeting ground for plant species originating from wide world regions, as Western Europe, Central Asia and Eastern Africa and other countries. Palestine is located in the Mediterranean region, being considered as one of the region of biodiversity in the world that should be subjected to conservation [20] [21]. Flora of Palestine is playing a role in economical important plants includes vegetables, crops and fruit trees, providing the local and international market with essential agricultural crops and it's very important used in field of medicine and research. In the other side, they are more than 2750 species of plants including 138 families that were estimated for Palestinian flora [3] [22] [23].

The main aims of the present study are to contribute to the knowledge of the flora of Palestine as endemic rare, and to study some of characteristics biologically and ecologically of plant in Palestine.

\section{Materials and Methods}

Flora of Palestine is important in medicine field and it is a role economical as fruit trees and vegetables, and to the know of flora of Palestine as endemic rare in the Mediterranean region, we selected a sampling areas in the regions of Hebron (south of Palestine); Jenin (north of Palestine); Jericho (east of Palestine and the area of Jordan valley) and Ramallah (center of Palestine), in which inventories or species were taken of 400 sampled plants in the locations previous. Forests, trees, herbaceous and shrub lands were sampled in order to obtain biological indicators for thermotype, ombrotype and to knowledge flora endemic rare at some of areas of Palestine. The inventories were made following Braun-Blanquet [24], and the Flora of Lebanon, Syria, Jordan, Negev, Sinai and Palestine were used for the floristic study. The absence of classification studies on the areas led us to run a statistical treatment on the 400 sampled of species. Moreover, we transformed the Braun-Blanquet species abundance-dominance values into those of Van der Maarel [25], and we used the classification of the earth of Salvador Rivas Martinez [26] [27] [28] [29] [30] to analyses of the bioclimate factors in Palestine, and data were used from Meteorology of Palestinian stations for the 35 years (1975-1998 and 2000-2008), addition to the vegetation was interpreted according to several methodological works in the world [31] [32] [33] [34]. 


\subsection{Study Area}

Palestine is located between longitudes $34^{\circ} 15^{\prime}$ and $35^{\circ} 40^{\prime}$ East and between latitudes $29^{\circ} 30^{\prime}$ and $33^{\circ} 15^{\prime}$ North. The geographic location of Palestine plays a major role in affecting the features of its flora and climate and the bioclimate diversity between the southern to northern parts, moreover, we selected the endemic rare species from the location of region Hebron, Jenin, Ramallah and Jericho cities, and their villages with the total area distance is $1145 \mathrm{~km}^{2}$ as in the Figure 1 , Table 1 \& Table 2.

Table 1. Coordinates of location studied, and its distance and evaluation of Palestine.

\begin{tabular}{ccccc}
\hline Location & Area $\mathbf{k m}^{2}$ & Latitude & Longitude & Elevation \\
\hline Jenin & 215 & $32^{\circ} 28^{\prime} \mathrm{N}$ & $35^{\circ} 18^{\prime} \mathrm{E}$ & $178 \mathrm{~m}$ \\
Ramallah & 250 & $31^{\circ} 89^{\prime} \mathrm{N}$ & $35^{\circ} 21^{\prime} \mathrm{E}$ & $856 \mathrm{~m}$ \\
Hebron & 570 & $31^{\circ} 32^{\prime} \mathrm{N}$ & $35^{\circ} 06^{\prime} \mathrm{E}$ & $1005 \mathrm{~m}$ \\
Jericho & 110 & $31^{\circ} 51^{\prime} \mathrm{N}$ & $35^{\circ} 27^{\prime} \mathrm{E}$ & $-260 \mathrm{~m}$ \\
\hline
\end{tabular}

Km: Kilometers, N: North, and E: East.

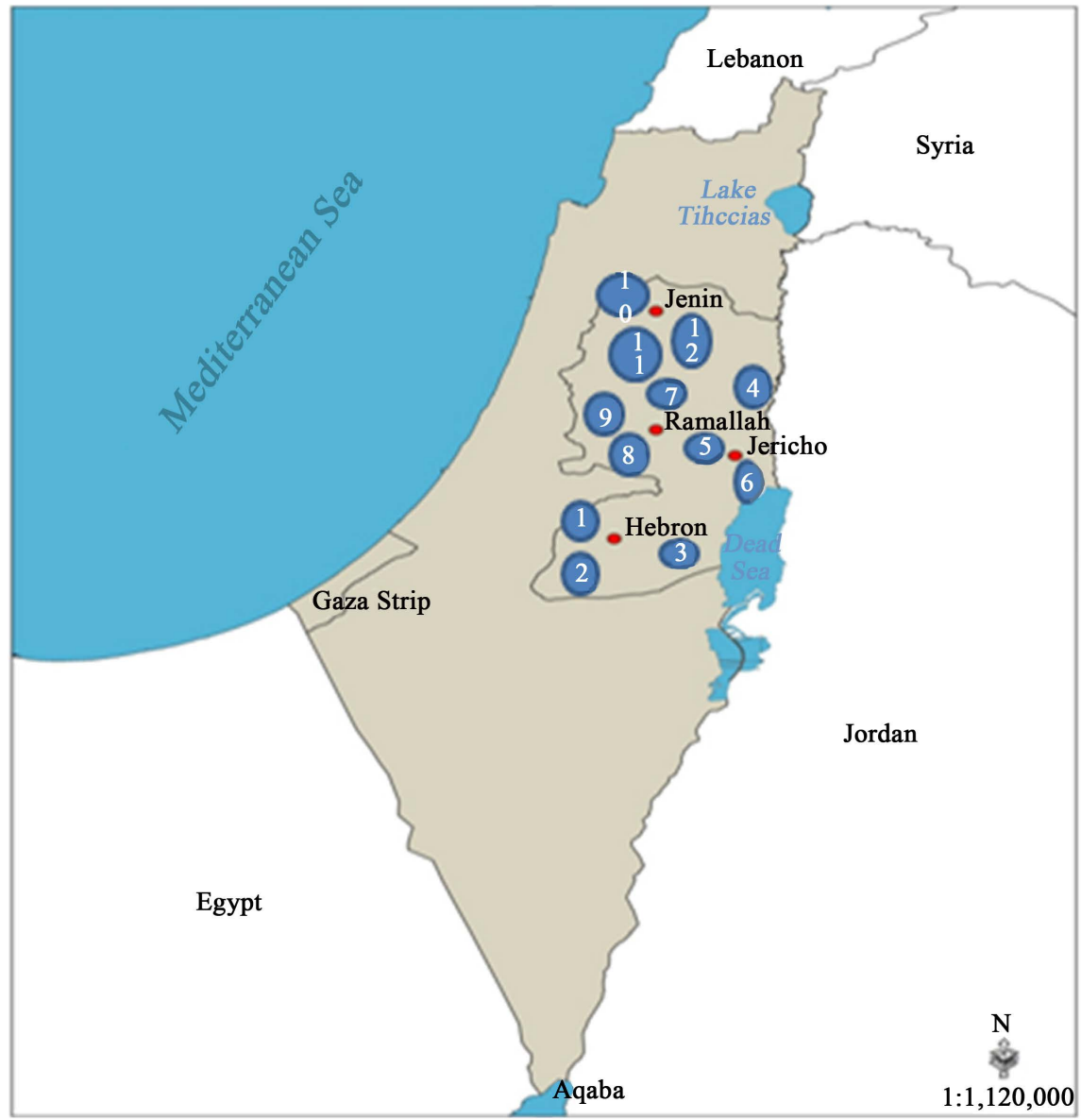

Figure 1. Details of the Furth stands chosen for vegetation analysis in the study area in Palestine. The cities of Hebron, Ramallah, Jenin and Jericho are representing red color in the figures. 
Table 2. Details of the elephant stands chosen for vegetation analysis in the area study of Palestine.

\begin{tabular}{cccc}
\hline Number & Location studied in the cities of Palestine & Precipitation & Elevation \\
\hline $\mathbf{1}$ & Idna & $473 \mathrm{~mm}$ & $500 \mathrm{~m}$ \\
$\mathbf{2}$ & Ad-Dhahiriya & $350 \mathrm{~mm}$ & $655 \mathrm{~m}$ \\
$\mathbf{3}$ & Yatta & $589 \mathrm{~mm}$ & $820 \mathrm{~m}$ \\
$\mathbf{4}$ & Al-Nuwaimeh & $190 \mathrm{~mm}$ & $-140 \mathrm{~m}$ \\
$\mathbf{5}$ & Tal Sultan & $180 \mathrm{~mm}$ & $-200 \mathrm{~m}$ \\
$\mathbf{6}$ & Wadi Al-Qalit & $170 \mathrm{~mm}$ & $-285 \mathrm{~m}$ \\
7 & Turmus'ayya & $490 \mathrm{~mm}$ & $720 \mathrm{~m}$ \\
$\mathbf{8}$ & Umm Safa & $560 \mathrm{~mm}$ & $630 \mathrm{~m}$ \\
9 & Qibya & $490 \mathrm{~mm}$ & $250 \mathrm{~m}$ \\
10 & Al-Yamon & $341 \mathrm{~mm}$ & $177 \mathrm{~m}$ \\
11 & Yabod & $625 \mathrm{~mm}$ & $385 \mathrm{~m}$ \\
12 & Methylone & $633 \mathrm{~mm}$ & $380 \mathrm{~m}$ \\
\hline
\end{tabular}

In the Table 2: Hebron area is representing the area study from number (1 3), and Jericho (4 - 6), Ramallah (7 - 9), while Jenin (10 - 12).

\subsection{Targeting and Collection of Plant Materials}

We studied four important areas extends from the north to the south of $\mathrm{Pa}$ lestine, in this study we took 400 samples of different species plants from Hebron (Idna, Ad-Dhahiriya, Yatta villages and Hebron city); Jenin (Jenin city, Al-Yamon, Methylone and Yabod); Jericho (Wadi Al-Qalt, Ain or Tal Sultan and Al-Nuwaimeh) and Ramallah (Umm Safa, Turmus'ayya and Qibya) (Table 2 and Table 4).

\section{Results and Discussion}

\subsection{Bioclimatology}

The location of the Palestine has given the study areas a tropical to a little humid climate [2] [3] [4], influenced by the mountains trade winds, geological and the topography of the regions, the climate is similar to that of the other Mediterranean basin. The annual average temperature is $\left(18^{\circ} \mathrm{C}-22^{\circ} \mathrm{C}\right)$, with little variation during night or day and few seasonal fluctuations. The hottest month is July and August, and the coldest is January. The annual rainfall distribution clearly reveals tow wet seasons, from September to November and November to March, while the dry season extends from June to September. The rainfall distribution reflects the direction of the trade winds, costal area, topography, temperature and the orientation of the mountain ranges, with a deceased rainfall to move from north to the south of Palestine, addition to the study area is influenced by the annual ombrothermic index value between (0.3 - 3.4), simple continentaly index value between (14.9 - 22), and compensated thermicity index value between (306/512) (Table 3), we used the following formulas to calculate the values 
Table 3. Bioclimatic belts and ombrotype in study area of Palestine.

\begin{tabular}{cccccc}
\hline Provinces & Thermotype & Ombrotype & $\left(I_{c}\right)$ & $\left(I_{o}\right)$ & $\left(I_{t} / I_{t c}\right)$ \\
\hline Ramallah & lower mesomediterranean & upper dry & 4.9 & $3.0-3.4$ & $306 / 306$ \\
Jericho & lower inframediterranean & upper arid & 22 & $0.3-1.0$ & $512 / 512$ \\
Hebron & lower mesomediterranean & upper dry & 16.3 & $3.2-3.4$ & $297 / 297$ \\
Jenin & lower inframediterranean & lower dry & 17.0 & $2.0-2.7$ & $468 / 468$ \\
\hline
\end{tabular}

Simple continentality index (Ic), ombrothermic index (Io) and compensated thermicity index (It/Itc).

of the various index Rivas Martínez (1996): Annual ombrothermic index, $I_{o}=$ $P_{p} / T_{p}$; simple continentality index, $I_{c}=T_{\max }-T_{\min }$; thermicity index, or where applicable compensated thermicity index, $I_{t} / I_{t c}=(T+M+m)$ 10. $P_{p}=$ positive precipitation and $T_{p}=$ positive temperature (in this case equivalent to annual precipitation and average annual temperature divided by 12 , as all the months have an average temperature above $\left.0^{\circ}\right) ; P=$ precipitation of the months indicated; $T$ = average temperature of the months indicated; $T_{\max }=$ maximum temperature of the averages of the warmest month of the year; $T_{\min }=$ minimum temperature of the averages of the coldest month of the year; $\mathrm{T}=$ Mean annual temperature; $M=$ Mean of the maximum temperature of the coldest month of the year; and $m=$ average of the minimum temperature of the coldest month of the year.

Nevertheless, they are variation to the altitude $(-250$ - 1040) meters on the sea level as temperature $\left(-3^{\circ} \mathrm{C}-42^{\circ} \mathrm{C}\right)$ and rainfall $(100-900$ millimeters). For this reason, temperatures of $0^{\circ} \mathrm{C}$ can be recorded in inner valleys over 900 meters during the winter months as Hebron and Ramallah. Hurricanes and storms dramatically change the climate from June to October, especially in the south of Palestine as Hebron, and the east area at Jericho. These hurricanes originate in the tropics close in the area of Sinai desert, Negev and the Jordan valley regions.

\subsection{Biogeographically \& Vegetation Analysis, and Origin of the Flora}

The flora of Palestine has 2.750 species [3] [22] [23] [35], of which 155 are endemic (6\% of the total flora), and Leguminaceae family for instance with its 268 species contains 21 endemics, while among 23 species of Iridaceae, eight are endemic [36]. The floristic analysis reveals a great variety of influences, since a large number of species on Palestine derived, by means of migratory routes, from the floras of tropical Golf Arab, north Africa, and tropical to humid in Asia and Mediterranean basin, on the other hand, we confirmed that the flora of the occupied Palestinian territories has Euro-Siberian; Sudano-Zambesian, Saharo-Arabian; Irano-Turnian; Americas, Australia and South \& north Africa; Mediterranean; and plant endemic, and it has nineteen principal plant communities such as Winter Deciduous (Montane) Forests, Carob and Terebinth Woodlands, savanna Mediterranean, Mediterranean, and sand, Maquis, Oak Woodlands, Lotus and Herbaceous Vegetation and others [36]. 
In the statistical treatment we obtained 53 endemic species are very rare (Figure 2), representing forests, Lotus and Herbaceous vegetation, copses and high shrub lands as:

Aegilops sharonensis Eig., Convolvulus secundus desr., Leopoldia bicolor Boiss., Rumex occultans Sam., Allium telavivense, Allium papillare, Anacamptis israelitica H. Baumann \& Dafni, Anthemis brachycarpa Eig, Anthemis leucanthemifolia Boiss., Aristida sieberiana Trin., Atractylis carduus Forssk., Ballota philistaea Bornm., Bromus rigidus Roth., Campanula sulphurea Boiss., Centaurea procurrens Spreng., Trisetaria koelerioides Melderis., Capparis spinosa L., Crocus aleppicus Baker., Cutandia philistaea Boiss. Echinops philistaeus Feinbrun \& Zohary, Erodium subintegrifolium Eig., Erodium telavivense Eig., Ferula samariae Zohary \& P. H. Davis, Gagea dayana Chodat \& Beauverd, Galium philistaeum Boiss, Iris atrofusca Baker, Iris atropurpurea Dinsmore, Iris vartanii Foster, Origanum dayi Post, Linaria joppensis Bornm., Lupinus palaestinus Boiss, Lycium schweinfurthii Bot., Maresia pulchella DC., Onopordum telavivense Eig., Paronychia palaestina Eig, Phlomis brachyodon Boiss., Picris amalecitana Eig., Plantago sarcop L., Polygonum palaestinum Zohary, Pyrus syriaca Boiss., Scandix blepharicarpa O. Cohen, Senecio joppensis Dinsm., Silene modesta Boiss., Silene papillosa Boiss., Silene telavivensis Zohary \& Plitmann, Tamarix aphylla L., Tordylium aegyptiacum L., Trifolium billardieri L.Trifolium palaestinum Boiss., Trifolium philistaeum Zohary, Suaeda palaestina Zohary \& Eig., Onopordum carduiforme Boiss. were influenced by climate as climatophilous, temperature, rainfall, deficit water, and sunrise, and bioclimate factors as annual ombrothermic index, compensated thermicity index, simple continentality index and soil water reserve and growing in upper inframediterranean, thermomediterranean-subhumid environments on carbonated substrates (rosary, light, and sandy soils) with neutral to a high $\mathrm{pH}$; the Mediterranean woodlands and shrublands as Convolvulus secundus desr., Rumex occultans Sam., and Ballota philistaea Bornm.; Palestine, Mediterranean costal as Aristida sieberiana Trin.; the Mediterranean Woodlands and Shrublands, Semi-steppe shrublands as

The name and extent of plant presence selected in the study area of Palestine

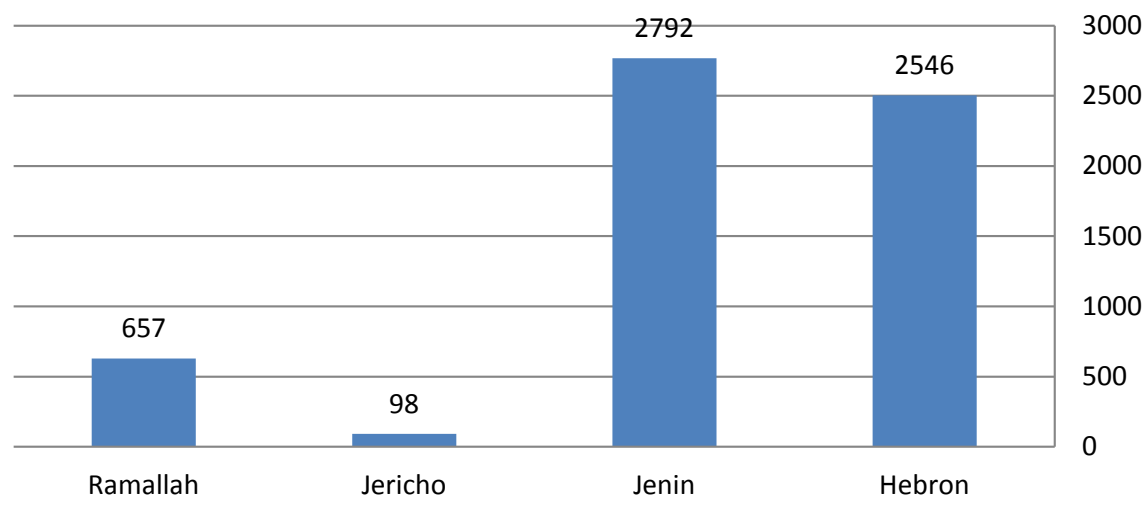

Figure 2. Repetition of the number of plants selected in the study area in Palestine. 
Erodium subintegrifolium Eig.; Golan, northern valleys, Nablus desert, Jenin, Dead Sea valley, Hebron, and northern Negev as Iris atrofusca Baker and Allium telavivense, and the rest of Palestinian mountains in Hebron, Jenin, Nablus, Ramallah Jericho as Iris atropurpurea Dinsmore, this leads us to propose, for the areas of the eastern Mediterranean.

Furthermore, according study area we indicated that the flora endemic rare has 53 species, which of them 13\% belong to Compositae family, 7.54\% Poaceae, Caryophyllaceae, Liliaceae and Papilionaceae families, 5.66\% Iridaceae family (Table 4), and the total repetition of the number of plants species selected in the study area are equals 6091, which of them $41.79 \%$ (2546 plant) in Hebron, 45.83\% (2792 plant) in Jenin, $1.60 \%$ (98 plant) in Jericho and $10.78 \%$ (657 plant) in Ramallah, as in the (Figure 2), and Anacamptis israelitica H. Baumann \& Dafni, Anthemis brachycarpa Eig., and Paronychia palaestina Eig. species were dominated and representinga high existed in the study area of Palestine (Figure 3). The regression coefficients $(\mathrm{R})$ are equal $0.801,0.771,0.001$, and 0.322 for Jenin, Hebron, Jericho and Ramallah respectively.

However, Tamarix aphylla L. should be included in the Mediterranean and Saharan-Arabian class Nerio-Tamaricetea [37]; and in Tamaricetalia [38] [39], Braun-Blanquet J. [40], the only order described to date, the absence of Tamarix gallica and Tamarix Africana, and the presence in Asiatic territories of Tamarix tetragyna, $T$. tetrandra, $T$. jordanis etc.

Moreover, distribution plants of the flora Palestinian area [22] comprises updated nomenclature, distribution and habit data for the species in the area covered by flora Palestinian [41]-[46]. However, we noted that the plants in Palestine are considered an important part of the plant to the Region Mediterranean basin, which is similar to many studies such as [3] [36] [47]. Nevertheless, there

Number of species cited in the study areas
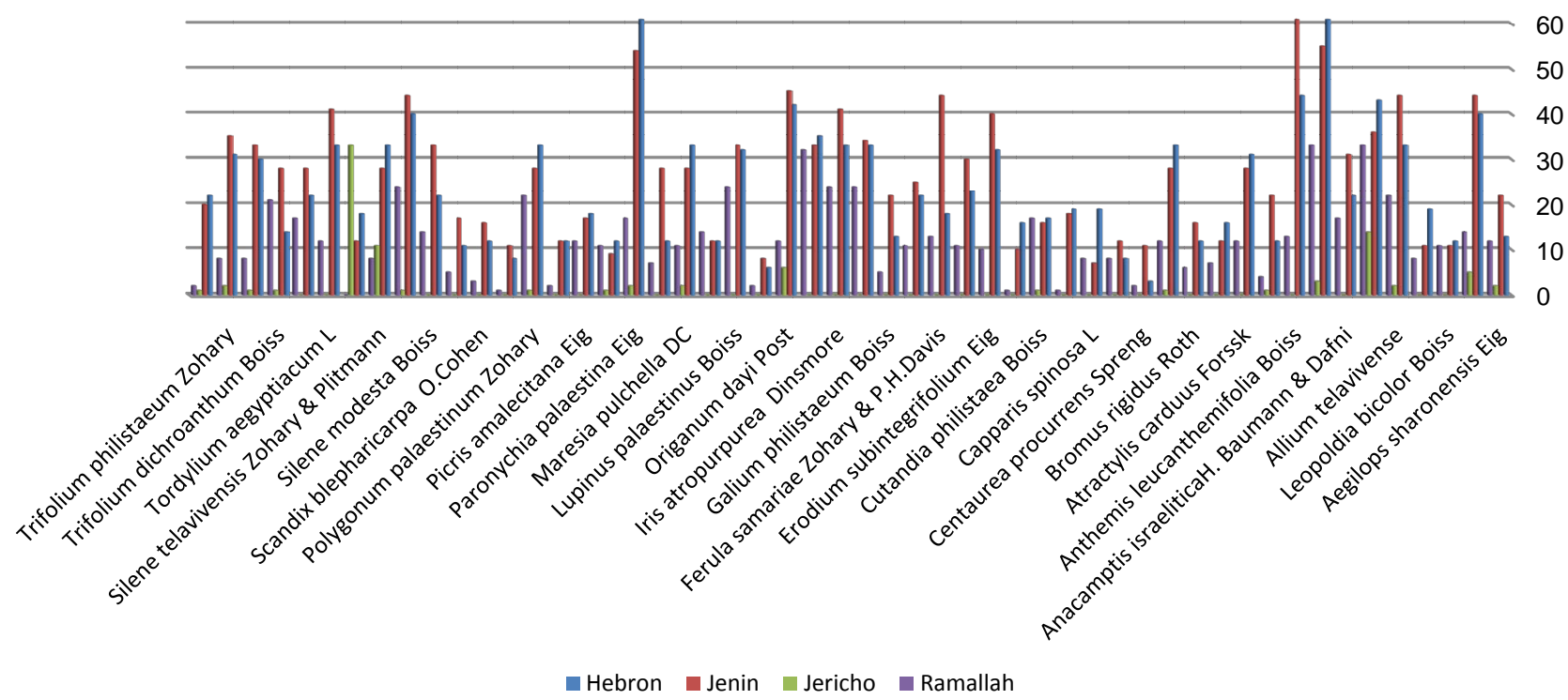

Figure 3. The name and extent of plant presence in the area studied in Palestine. 
Table 4. Synthetic representation of plant and its repetitions of the number of plants in study area sampled.

\begin{tabular}{|c|c|c|c|c|c|c|}
\hline Synthetic representation of plant & Hebron & Jenin & Jericho & \multicolumn{3}{|c|}{ Ramallah } \\
\hline Altitude in $\mathrm{m} 1=10$ & 690 & 370 & -220 & 670 & & \\
\hline Surface in $\mathrm{m}^{2}$ & 200 & 300 & 100 & 70 & & \\
\hline Cover rate \% & 60 & 65 & 75 & 70 & & \\
\hline Average height of veg. in $\mathrm{m}$ & 1.5 & 2 & 2 & 2.5 & & \\
\hline slope $\%$ & 5 & 15 & 10 & 25 & & \\
\hline Orientation & $\mathrm{W}$ & $\mathrm{N}$ & $\mathrm{E}$ & $S$ & & verage Family \\
\hline \multicolumn{7}{|l|}{ Species } \\
\hline Aegilops sharonensis Eig. & 13 & 22 & 2 & 12 & 12.25 & Poaceae \\
\hline Convolvulus secundus desr. & 40 & 44 & 5 & 14 & 25.75 & Convolvulaceae \\
\hline Leopoldia bicolor Boiss. & 12 & 11 & 0 & 11 & 8.5 & Liliaceae \\
\hline Rumex occultans Sam. & 19 & 11 & 0 & 8 & 9.5 & Polygonaceae \\
\hline Allium telavivense & 33 & 44 & 2 & 22 & 25.25 & Liliaceae \\
\hline Allium papillare & 43 & 36 & 14 & 33 & 31.5 & Liliaceae \\
\hline $\begin{array}{l}\text { Anacamptis israelitica } \\
\text { H. Baumann \& Dafni }\end{array}$ & 22 & 31 & 0 & 17 & 17.5 & orciddaceae \\
\hline Anthemis brachycarpa Eig & 61 & 55 & 3 & 33 & 38 & Compositae \\
\hline Anthemis leucanthemifolia Boiss. & 44 & 61 & 0 & 13 & 29.5 & Compositae \\
\hline Aristida sieberiana Trin. & 12 & 22 & 1 & 4 & 9.75 & Poaceae \\
\hline Atractylis carduus Forssk. & 31 & 28 & 0 & 12 & 17.75 & Compositae \\
\hline Ballota philistaea Bornm. & 16 & 12 & 0 & 7 & 8.75 & Labiatae \\
\hline Bromus rigidus Roth. & 12 & 16 & 0 & 6 & 8.5 & Poaceae \\
\hline Campanula sulphurea Boiss. & 33 & 28 & 1 & 12 & 18.5 & Campanulaceae \\
\hline Centaurea procurrens Spreng. & 3 & 11 & 0 & 2 & 4 & Compositae \\
\hline Trisetaria koelerioides Melderis. & 8 & 12 & 0 & 8 & 7 & Poaceae \\
\hline Capparis spinosa $\mathrm{L}$. & 19 & 7 & 0 & 8 & 8.5 & Capparaceae \\
\hline Crocus aleppicus Baker. & 19 & 18 & 0 & 1 & 9.5 & Iridaceae \\
\hline Cutandia philistaea Boiss. & 17 & 16 & 1 & 17 & 12.75 & Poaceae \\
\hline Echinops philistaeus Feinbrun \& Zohary & 16 & 10 & 0 & 1 & 6.75 & Compositae \\
\hline Erodium subintegrifolium Eig. & 32 & 40 & 0 & 10 & 20.5 & Geraniaceae \\
\hline Erodium telavivense Eig. & 23 & 30 & 0 & 11 & 16 & Geraniaceae \\
\hline Ferula samariae Zohary \& P.H.Davis & 18 & 44 & 0 & 13 & 18.75 & Apiaceae \\
\hline Gagea dayana Chodat \& Beauverd & 22 & 25 & 0 & 11 & 14.5 & Liliaceae \\
\hline Galium philistaeum Boiss & 13 & 22 & 0 & 5 & 10 & Rubiaceae \\
\hline Iris atrofusca Baker & 33 & 34 & 0 & 24 & 22.75 & Iridaceae \\
\hline Iris atropurpurea Dinsmore & 33 & 41 & 0 & 24 & 24.5 & Iridaceae \\
\hline Iris vartanii Foster & 35 & 33 & 0 & 32 & 25 & Iridaceae \\
\hline
\end{tabular}




\section{Continued}

\begin{tabular}{|c|c|c|c|c|c|c|}
\hline Origanum dayi Post & 42 & 45 & 6 & 12 & 26.25 & Labiatae \\
\hline Linaria joppensis Bornm. & 6 & 8 & 0 & 2 & 4 & Scrophulariaceae \\
\hline Lupinus palaestinus Boiss & 32 & 33 & 0 & 24 & 22.25 & Papilionaceae \\
\hline Lycium schweinfurthii Bot. & 12 & 12 & 0 & 14 & 9.5 & Solanaceae \\
\hline Maresia pulchella $D C$. & 33 & 28 & 2 & 11 & 18.5 & Cruciferae \\
\hline Onopordum telavivense Eig. & 12 & 28 & 0 & 7 & 11.75 & Asteraceae \\
\hline Paronychia palaestina Eig & 61 & 54 & 2 & 17 & 33.5 & Caryophyllaceae \\
\hline Phlomis brachyodon Boiss. & 12 & 9 & 1 & 11 & 8.25 & Labiatae \\
\hline Picris amalecitana Eig. & 18 & 17 & 0 & 12 & 11.75 & Compositae \\
\hline Plantago sarcop $\mathrm{L}$. & 12 & 12 & 0 & 2 & 6.5 & Plantaginaceae \\
\hline Polygonum palaestinum Zohary & 33 & 28 & 1 & 22 & 21 & Polygonaceae \\
\hline Pyrus syriaca Boiss. & 8 & 11 & 0 & 1 & 5 & Rosaceae \\
\hline Scandix blepharicarpa O.Cohen & 12 & 16 & 0 & 3 & 7.75 & Apiaceae \\
\hline Senecio joppensis Dinsm. & 11 & 17 & 0 & 5 & 8.25 & Compositae \\
\hline Silene modesta Boiss. & 22 & 33 & 0 & 14 & 17.25 & Caryophyllaceae \\
\hline Silene papillosa Boiss. & 40 & 44 & 1 & 24 & 27.25 & Caryophyllaceae \\
\hline Silene telavivensis Zohary \& Plitmann & 33 & 28 & 11 & 8 & 20 & Caryophyllaceae \\
\hline Tamarix aphylla L. & 18 & 12 & 33 & 0 & 15.75 & Tamaricaceae \\
\hline Tordylium aegyptiacum $\mathrm{L}$. & 33 & 41 & 0 & 12 & 21.5 & Apiaceae \\
\hline Trifolium billardieri $\mathrm{L}$. & 22 & 28 & 0 & 17 & 16.75 & Fabaceae \\
\hline Trifolium dichroanthum Boiss. & 8 & 3 & 0 & 5 & 4 & Papilionaceae \\
\hline Trifolium dichroanthum Boiss. & 8 & 8 & 1 & 4 & 5 & Papilionaceae \\
\hline Trifolium philistaeum Zohary & 8 & 8 & 3 & 3 & 11 & Papilionaceae \\
\hline Trifolium palaestinum Zohary \& Eig. & 10 & 8 & 2 & 4 & 4 & Chenopodiaceae \\
\hline Onopordum carduiforme Eig. & 10 & 5 & 1 & 4 & 5 & Compositae \\
\hline
\end{tabular}

Average: Representing average of each of plant in the total sampled, total of plant repetitions in study area is 6091 , the standard deviation of the vegetation analysis is equal 14.43 .

coexistence between flora of Palestine due to the biodiversity, the topography, the nature of the climate and bioclimatic factors.

\section{Conclusions}

Within the historic lands of Palestine, the number of plant species is 2750 in an area of $27,000 \mathrm{~km}^{2}$, of which them 2485 species in the area of occupied Palestinian territories year 1967 with a $5600 \mathrm{~km}^{2}$, whereas the flora of study area (Hebron, Jenin, Ramallah and Jericho) of Palestine has 1881 species (with the area of $1145 \mathrm{~km}^{2}$ ), 53 plant species of which are endemically rare such as Paronychia palaestina Eig, Trifolium palaestinum Boiss., Trifolium philistaeum Zohary, Suaeda philistaeum Zohary and others, representing forests, copses, herbaceous and 
high shrublands influenced by climate as climatophilous and edaphohygrophilic, and bioclimate factors as ombrotype and thermotype.

Palestine flora and biodiversity belong to arid, semi-arid, dry, sub-humid and humid ombrotype and lower inframediterranean to mesomediterranean environments thermotype in Mediterranean region. Consequently, Palestine's geographical position has been, both its blessing and its curse, located at the meeting point between Eurasia and Africa and plants of three continents have interacted and spread throughout history. Moreover, the flora endemic species representing a more present in the area of Hebron and Jenin, because Hebron is affected by climate and biodiversity of Mediterranean basin, topography, Dead Sea, Red Sea, Sinai desert and Negev and the mountains highland, meanwhile Jenin is affected by Mediterranean basin, and Jordan valley and Al-Aghwar, and other factors.

In the end, we need achieve some of projects and researches to knowledge all of Palestine plant and established plants bank.

\section{References}

[1] Ighbareyeh, J.M.H., Cano-Ortiz, A. and Cano, E. (2014) Biological and Bioclimatic Basis to Optimize Plant Production: Increased Economic Areas of Palestine. Agricultural Science Research Journal, 4, 10-20.

[2] Ighbareyeh, J.M.H., Cano-Ortiz, A. and Cano, E. (2014) Case Study: Analysis of the Physical Factors of Palestinian Bioclimate. American Journal of Climate Change, 3, 223-231. https://doi.org/10.4236/ajcc.2014.32021

[3] Ighbareyeh, J.M.H., Cano-Ortiz, A., Suliemieh, A.A.A., Ighbareyeh, M.M.H. and Cano, E. (2014) Phytosociology with Other Characteristic Biologically and Ecologically of Plant in Palestine. American Journal of Plant Sciences, 5, 3104-3118. https://doi.org/10.4236/ajps.2014.520327

[4] Ighbareyeh, J.M.H., Cano-Ortiz, A., Suliemieh, A.A.A., Ighbareyeh, M.M.H. and Cano, E. (2015) Assessing Crop Yield Sustainability under the Climatic and Bioclimatic Change in the Area of Palestine. American Journal of Climate Change, 4, 48-56. https://doi.org/10.4236/ajcc.2015.41005

[5] Ortiz, A.C., Ighbareyeh, J.M.H. and Cano, E. (2014) Bioclimatic Applications and Soil Indicators for Olive Cultivation (South of the Iberian Peninsula). Global Advanced Research Journal of Agricultural Science, 3, 433-438. http://garj.org/garjas/index.htm

[6] Ighbareyeh, J.M.H., Cano-Ortiz, A., Suliemieh, A.A.A., Ighbareyeh, M.M.H. and Cano, E. (2015) Study of Biology and Bioclimatology of Date Palm (Phoenix dactylifera L.) to Optimize Yield and Increase Economic in Jericho and Gaza Cities of Palestine. International Journal of Research Studies in Biosciences, 3, 1-8.

[7] Ighbareyeh, J.M.H., Cano-Ortiz, A., Suliemieh, A.A.A., Ighbareyeh, M.M.H. and Cano, E. (2015) Assessment of Biology and Bioclimatology of Plant to Increase Economic in Palestine. International Journal of Research Studies in Biosciences, 3, 1-8.

[8] Ighbareyeh, J.M.H., Cano-Ortiz, A., Suliemieh, A.A.A., Ighbareyeh, M.M.H. and Cano, E. (2015) Biology and Bioclimatology Applied on Plant in Palestine. International Journal of Research Studies in Biosciences, 3, 79-86.

[9] Ighbareyeh, J.M.H., Cano-Ortiz, A., Suliemieh, A.A.A., Ighbareyeh, M.M.H. and Cano, E. (2015) Study Effect of Biology and Bioclimatology Applied on Plant in the Area of Hebron at the South of Palestine. International Journal of Research Studies 
in Biosciences, 3, 56-64.

[10] Ighbareyeh, J.M.H., Cano-Ortiz, A., Suliemieh, A.A.A., Ighbareyeh, M.M.H. and Cano, E. (2015) Effect of Biology and Bioclimatology Applied on Plant in the Area of Jenin at the North of Palestine. International Journal of Research Studies in Bioscience, 3, 1-6.

[11] Ighbareyeh, J.M.H., Cano-Ortiz, A., Suliemieh, A.A.A., Ighbareyeh, M.M.H. and Cano, E. (2015) Study of Climatology and Bioclimatology Applied on Plant in Area of Hebron in Palestine. International Multidisciplinary Research Journal, 5.

[12] Ighbareyeh, J.M.H., Cano-Ortiz, A., Cano Carmona, E., Ighbareyeh, M.H. and Suliemieh, A.A. (2015) Modeling of Biology and Bioclimatology Applied on Plant in Palestine. Swift Journal of Agricultural Research, 1, 21-27.

http://www.swiftjournals.org/sjar

[13] Ighbareyeh, J.M.H., Cano-Ortiz, A., Suliemieh, A.A.A., Ighbareyeh, M.M.H. and Cano, E. (2015) Effect of Biology and Bioclimatology Applied Studies on Plant in the Area of Jerusalem in Palestine. International Journal of Research Studies in Biosciences, 3, 135-140. http://www.arcjournals.org

[14] Ighbareyeh, J.M.H., Cano-Ortiz, A., Cano, E., Mohammed, M.H.I. and Suliemieh, A.A.A. (2016) Effect of Biology, Climatic and Bioclimatic Applied Studies on Plant: To Increase the Economy and Maintaining Food Security in the Jerusalem Occupied of Palestine. International Journal of Research Studies in Biosciences, 4, 54-60. http://www.arcjournals.org

[15] Ighbareyeh, J.M.H., Cano-Ortiz, A., Suliemieh, A.A.A., Ighbareyeh, M.M.H. and Cano, E. (2016) Study of Biology and Bioclimatology Applied of Apricot (Prunus Armeniaca L.): To Increase the Economy and Maintaining Food Security in Palestine. International Journal of Research Studies in Biosciences, 4, 12-20. http://www.arcjournals.org

[16] Ighbareyeh, J.M.H., Cano-Ortiz, A., Suliemieh, A.A.A., Ighbareyeh, M.M.H. and Cano, E. (2016) Modeling of Biology and Bioclimatology Applied Studies on Plant in Palestine. International Journal of Development Research, 6, 9585-9590.

http://www.journalijdr.com

[17] Ighbareyeh, J.M.H., Cano-Ortiz, A., Suliemieh, A.A.A., Ighbareyeh, M.M.H., Cano, E. and Hijjeh, S. (2016) Effect of Bioclimate Factors on Olive (Olea Europea L.) Yield: To Increase the Economy and Maintaining Food Security in Palestine. International Journal of Development Research, 6, 10648-10652.

http://www.journalijdr.com

[18] Ighbareyeh, J.M.H., Cano-Ortiz, A., Cano Carmona, E., Ighbareyeh, M.M.H., Suliemieh, A.A.A. and Hijjeh, S. (2017) Impact of Bioclimate and Climate Factors on Plant Yield in the Area of Jenin at the North of Palestine. International Journal of Current Research, 9, 44529-44535.

[19] Zohary, M. (1962) Plant Life of Palestine. Ronald Press Company, New York.

[20] Médail, F. and Quézel, P. (1997) Hot-Spots Analysis for Conservation of Plant Biodiversity in the Mediterranean Basin. Annals of the Missouri Botanical Garden, 84, 112-127. https://doi.org/10.2307/2399957

[21] Myers, N. and Cowling, R. (1999) Mediterranean Basin. In: Mittermeier, R.A., Myers, N. and GoettschMittermeier, C., Eds., Hotspots Earth's Biologically Richest and Most Endangered Terrestrial Ecoregions, CEMEX and Conservation International, Mexico City, 254-267.

[22] Danin, A. (2004) Distribution Altas of Plants in Flora Palestine Area. 2nd Edition, Academy of Science and Humanities, Jerusalem, 520. 
[23] Sawalha, K. (2005) Plant Biodiversity. Al-QudsUniversity.

[24] Braun-Blanquet, J. (1979) Fitosociología. Bases para el estudio de las comunidades vegetales. Blume, Madrid, $820 \mathrm{p}$.

[25] Van Der Maarel, E. (1979) Transformation of Cover-Abundance Values in Phytosociology and Its Effects on Community Similarity. Vegetatio, 39, 97-114. https://doi.org/10.1007/BF00052021

[26] Rivas Martinez, S., Sanchez Mata, D. and Costa, M. (1999) North American Boreal and Western Temperate Forest Vegetation (Syntaxonomical Synopsis of the Potential Natural Plant Communities of North America, II). Itinera Geobot, 12, 5-316.

[27] Rivas Martínez, S. (1996) Clasificación bioclimática de la Tierra. Folia Bot Matritensis, 16, 1-20.

[28] Rivas Martinez, S. (2004) Worldwide Bioclimatic Classification System. http://www.globalbioclimatics.org

[29] Rivas-Martinez, S. (2008) Global Bioclimatic. http://www.globalbioclimatics.org

[30] Rivas-Martínez, S., Rivas-Sáenz, S. and Penas, A. (2011) Worldwide Bioclimatic Classification System. Global Geobotany, 1, 1-634.

[31] Biondi, E. (2011) Phytosociology Today: Methodological and Conceptual Evolution. Plant Biosystems, 145, 19-29. https://doi.org/10.1080/11263504.2011.602748

[32] Pott, R. (2011) Phytosociology: A Modern Geobotanical Method. Plant Biosystems, 145, 9-18. https://doi.org/10.1080/11263504.2011.602740

[33] Rivas-Martínez, S. (2004) Sinopsis biogeográfica, bioclimática y vegetacional de América del Norte. Fitosociología, 41, 19-52.

[34] Rivas-Martínez, S. (2005) Notions on Dynamic-Catenal Phytosociology as a Basis of Landscape Science. Plant Biosystems, 139, 135-144. https://doi.org/10.1080/11263500500193790

[35] Applied Research Institute Jerusalem (ARIJ) (2006-2009) GIS Database. http://vprofile.arij.org/hebron/pdfs/Al\%20Heila_pro.pdf

[36] Sc. Norman Ali Bassam Ali TaherKhalaf-Sakerfalke von Jaffa (2009) The Article Was Published in "Gazelle: The Palestinian Biological Bulletin". Number 91, July 2009, Rajab 1430, 1-31.

[37] Braun-Blanquet, J. and Bolos, O. (1958) Les groupementsvégétaux du bassinmoyen de l'Ebre et leurdynamisme. Anal. Aula Dei, 5, 1-266.

[38] Braun-Blanquet, J. (1952) Les groupementsvegetaux del France meditérranéenne. Editions C.N.R.S., Montpellier.

[39] Braun-Blanquet, J. (1952) Irradiation seuropeennesdans la vegetation de la Kroumirie. Vegetatio, 4, 182-194. https://doi.org/10.1007/BF00297018

[40] Rivas-Martínez, S., Díaz, T.E., Fernández-González, F., Izco, J., Loidi, J., Lousa, M. and Penas, E. (2002) Vascular Plant Communities of Spain and Portugal. Itinera Geobotanica, 15, 433-922.

[41] Zohary, M. (1966) Flora Palaestina. Part 1, Text Equisetaceae to Moringaceae. Israel Academy of Science and Humanities, Jerusalem, 346.

[42] Zohary, M. (1972) Flora Palaestina. Part 2, Text Platanaceae to Umbelliferae. Israel Academy of Science and Humanities, Jerusalem, 656.

[43] Dothan, F.N. (1978) Flora Palaestina, Part Three, Text Ericaceae to Compositae. Israel Academy of Science and Humanities, Jerusalem, 481.

[44] Dothan, F.N. (1986) Flora Palaestina, Part Four Plates, Text Alismtaceae to Orchidaceae. Academy of Science and Humanities, Jerusalem, 525. 
[45] Danin, A. and Orshan, G. (1999) Vegetation of Israel: I. Desert and Coastal Vegetation. Buckhuys, Leiden, 341.

[46] Danin, A. and Feinbrun-Dothan, N. (1991) Analytical Flora of Eretz-Israel. CANA Publishing House Ltd., Jerusalem.

[47] Danin, A. (2000) The Nomenclature News of Flora Palaestina. Flora Mediterranean, 10, 109-127.

Submit or recommend next manuscript to OALib Journal and we will provide best service for you:

- Publication frequency: Monthly

- 9 subject areas of science, technology and medicine

- Fair and rigorous peer-review system

- Fast publication process

- Article promotion in various social networking sites (LinkedIn, Facebook, Twitter, etc.)

- Maximum dissemination of your research work

Submit Your Paper Online: Click Here to Submit

Or Contact service@oalib.com 